\title{
Source to Subject: Fiona Foley's Evolving Use of Archives
}

\author{
Marina Tyquiengco ${ }^{+}$ \\ Department of History of Art and Architecture, University of Pittsburgh, Pittsburgh, PA 15260, USA; \\ mat186@pitt.edu \\ + Note: Marina Tyquiengco is a CHamoru scholar of contemporary Indigenous art. She wrote her master's \\ thesis in 2016 on reuse of ethnographic photography by contemporary Aboriginal artists. Her dissertation \\ project, also at the University of Pittsburgh, explores embodiment as a central feature of the work of four \\ contemporary Indigenous artists. Her article "Black Velvet: Aboriginal Womanhood in the Art of Fiona Foley" \\ examines Foley's works titled Black Velvet from 1996-2017 and was published in Feminist Studies. She is \\ currently working with Foley on an entry about her artwork for the National Gallery of Australia. In fall 2020, \\ she will teach a course on Indigenous Art at Brown University.
}

Received: 24 June 2020; Accepted: 3 July 2020; Published: 9 July 2020

\begin{abstract}
Since the 1980s, multidisciplinary artist Fiona Foley has created compelling art referencing her history, Aboriginal art, and her Badtjala heritage. In this brief essay, the author discusses an early series of Foley's work in relation to ethnographic photography. This series connects to the wider trend of Indigenous artists creating art out of 19th century photographs intended for distribution to non-Indigenous audiences. By considering this earlier series of her work, this text considers Foley's growth as a truly contemporary artist who uses the past as inspiration, invoking complicated moments of encounter between Europeans and Aboriginal Australians and their afterimages.
\end{abstract}

Keywords: photography; Fraser Island; Badtjala; contemporary art

The topic of decolonizing genealogy is especially compelling in the context of the oeuvre of Fiona Foley (Badtjala people, Wondunna clan, Fraser Island, Australia b. 1964) for many reasons, including her long-held emphasis on history. As a practicing artist for more than 30 years, Foley's work has shifted and evolved. In her approach to art, she chooses her mediums-which have ranged from installation, public sculpture, photographic series, and multimedia work-based on the particular ideas she wants to convey in each project. While studying at East Sydney Technical College, Foley first began to incorporate what could be termed as general Aboriginal symbols into her artistic practice (Genocchio 2001, p. 39). By the mid 1980s, she began to explore her own Badtjala history and imagery from the coast of southern Queensland. Her wide-ranging artistic practice is enriched by her extensive education, both in the Western context through her degrees, and at home, where she learned about her culture and connection to K'Gari/Fraser Island. Her mother, Shirley Foley, was an important teacher-and scholar in her own right—as she published the Badtjala-English dictionary, republished by Fiona Foley in 2019 (Foley 2018; Kembrey 2020).

Consistently, Foley has shown her deft hand in research, utilizing the colonial institutions of libraries and archives for her own artistic aims. The reuse of these archival images imbues life back to their subjects, and honors these images as signs of survival, in spite of their likely original intent as fancies for a white Australian public (Pinney 2011; Lydon 2014). Starting in the 1980s, many artists globally looked to the archives and other sources of imagery and photographs, engaging in practices of reuse, borrowing, and appropriation. Art historian Hal Foster famously characterized these sets of practices in his article, "The Artist as Ethnographer," noting the contemporary turn to the archive (Foster 1996, pp. 177-2003). More recently, scholar Christopher Pinney examined how contemporary 
artists from West Africa, Australia, and India recontextualize, remix, and recreate anthropological photography to question its original aims and embedded authority (Pinney 2011, pp. 132-39). In North America, First Nations artists such as Carl Beam (Ojibwa, 1943-2005) and Jane Ash Poitras (Cree, b. 1951) created multimedia work with historical and documentary photographs of First Nations people in the 1980s and 1990s (Martin and McMaster 1992, pp. 164-67). In the United States, artists like James Luna and Jimmie Durham explored performance and installation, to consider the role of Native Americans in museums. In Australia, many contemporary Aboriginal artists incorporated photographs of Aboriginal people in their art, such as Leah King-Smith with her Patterns of Connection series from 1991, in which the artist layered 19th century photographs of Aboriginal people with recent landscape images, creating a haunting effect (Tyquiengco 2016). To date, there has been no global study of the reuse of ethnographic photography, though a diverse range of artists from settler-colony and post-colonial nations engaged in this practice at relatively the same time. Rather than consider these practices as a set of trends or appropriations, it is instead useful to consider that non-Western and Indigenous artists were looking back to look forward due to expanded interest in their work and opportunities for exhibition, amid a still unequal, and increasingly globalized world.

Tracing a genealogy of Foley's photography practices demonstrates a move from using archival works as subject material to reinterpreting history and the archive through more elaborate staged photographic series (Helmrich 2009; Allas 2010). Her practice coincides with contemporary art practices globally, but Foley takes an especially personal turn to the types of photographs she reused and recreated. In 1994, she created the series Badtjala Woman and Native Blood where she recreated archival photographs of a Badtjala woman with her own body as a way to honor this ancestor and create her own image. Over the years, her practice of engaging the archive to connect with the genealogy of the Badtjala has expanded to include the artist as a subject, witness, and/or participant of many series including (but not limited to) Wild Times Call (2001), HHH (2004), Nulla 4 Eva (2009), and The Oyster Fishermen (2012). In 2017, she staged an expansive photographic and sculptural series, Horror Has a Face, as part of her PhD research, at Griffith University which was inspired by the discovery of large burial ground on K'gari (Fraser Island) at Bogimbah Creek Mission (Martin-Chew 2017).

Within her larger body of work, I would like to consider a suite of early works by Foley, which includes an image of an archival image that became an inspiration for Badtjala Woman and Native Blood later in her career (McDonald 2000, p. 43). In 1988, Foley created Survival, I-IV, an etching series of four images on two album pages with 1899 archival photographs of Badtjala people from the John Oxley State Library of the State Library of Queensland. The four simple black and white photo etchings on brown paper recast archival images as personal ones. Resembling pages of a photo album, two different archival photographs of Badtjala people are paired with the same archival photograph of shell middens, or piles of shell refuse, which serve as physical evidence of past peoples for anthropologists (Sinclair 1990, pp. 65-68). Matted together, Survival I-II appear as two works rather than four, with the images of Badtjala people reconnected to the midden piled beach, indicating the mutuality of the relationship between people and country. See Figures 1 and 2.

According to the Badtjala cosmology, K'gari, a woman spirit figure, created K'gari (Fraser Island), filling it with beautiful plants, animals, and beaches; she loved the island so much that she begged Yidingie, an ancestral carpet snake figure, to stay and he allowed her to lay down and become part of it (Taylor et al. 2009). Fittingly then, Foley's Survival series begins with an image of a woman. In Survival I, a Badtjala woman standing in front of a studio backdrop looks off to the side. She is barefoot, wearing a skirt at her waist, topless, and adorned in crisscrossing shell necklaces. The black and white landscape photograph of Survival II, a wide-angle expanse of shell midden and sand with no visible figures, could not be farther from the quiet tree lined studio backdrop of Survival I. The choice of this archival image of the island is important because the shell midden piles have helped archaeologists to understand Aboriginal occupation in K'gari over time and specifically to make claims about their technology and tools (Courtney and McNiven 1998). The shells show Badtjala presence as remnants they have left on the land and demonstrate their continual connection to their country. 


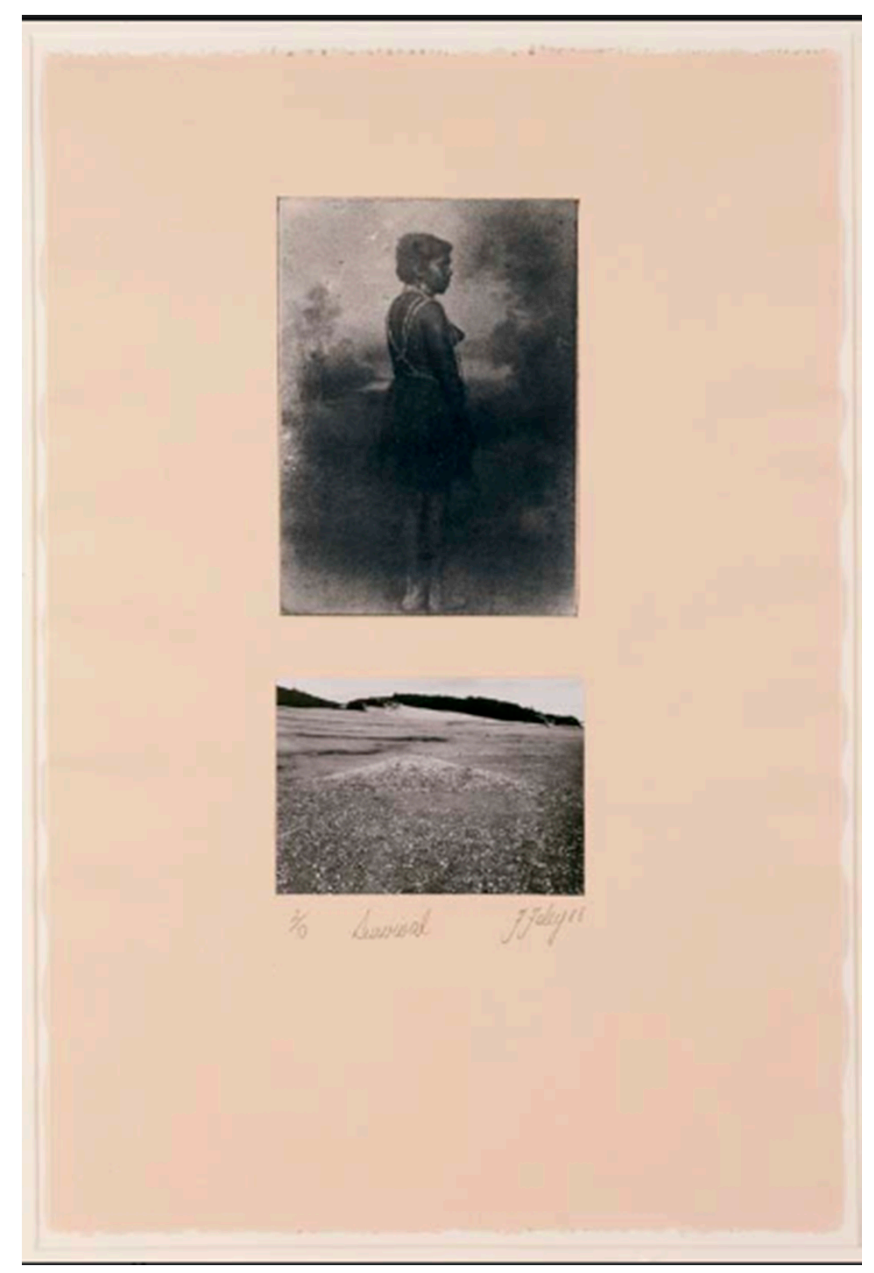

Figure 1. Fiona Foley's Survival I, II (1988). Photo etching and collage on brown paper. Edition 2/10. Two of four sheets: $56.5 \times 38 \mathrm{~cm}$ (each). Courtesy of Queensland Art Gallery and Gallery of Modern Art, Brisbane, Australia.

Survival III presents a Badtjala man posing outdoors. With his right arm, he holds a boomerang above his head, which evokes a hunting posture. However, his spread leg stance and hanging left arm indicate a more orchestrated scene; he may have been posing for the photographer for a while. His body appears tall and powerful, reflective of Badtjala people at the time of contact who were large and vigorous due to their varied diet (Taylor et al. 2009). Barefoot and facing the sun, this man appears to be humoring the photographer with no prey in mind. Like the Badtjala woman's photograph, this image has been used in other media to represent the physical prowess of the Badtjala people and their resistance to colonial encroachment over time (Williams 1982; Taylor et al. 2009).

Through their title, this series draws our attention to the question of survival. Archival photographs are held up as authentic representations of Indigenous people, which implicitly questions the authenticity of contemporary people. However, in Foley's hands, these photographs mean survival, rather than decline. When Foley repurposed these photographs in 1988, the Badtjala people had no recognition of their claim to $\mathrm{K}^{\prime}$ gari. Badtjala custodianship and continued stewardship of the island was finally recognized by the Australian Commonwealth Government in 2014 by the granting of Native Title (Buchanan et al. 2014). Significantly, Native Title is a recognition of the traditional ownership of the land, an acknowledgment of the connection between Badtjala people and $\mathrm{K}^{\prime}$ gari. It is not the same as ownership and Badtjala people's access to K'gari remains limited.

Juxtaposed to the land, this Badtjala man and woman's connection endures as strong as Foley's own tie to K'gari. Unstated in these images is that the land and people need each other to survive. 
Throughout her diverse career, Fiona Foley has moved from use of the archive as subject, to use of the archive as inspiration, staging ever more daring re-imaginings of history, such as Horror has a Face (2017). Starting from the archival images themselves, Foley's desire to honor the legacy of Badtjala people is apparent. Because of colonial frontier wars, the numbers of Badtjala people dwindled to less than 100 in the late 19th century (Taylor et al. 2009). But the Badtjala people survived. A decade after creating Survival I-IV, Foley wrote a pithy essay on her conception of the legacy of Eliza Fraser, the white woman for whom Fraser Island is officially named, reflecting her knowledge of history and critical race theory, titled aptly, "A Blast from the Past." In reference to the member of the Badtjala woman photograph used in Survival I-IV, Foley wrote that, "Yet I live in hope that my heroine could be your heroine, as she defies all odds with an unspoken eloquence of spunk" (Foley 1999, p. 167). Weaponizing herself with all manner of knowledge, Foley has positioned herself to be her own Badtjala heroine, to thrive.

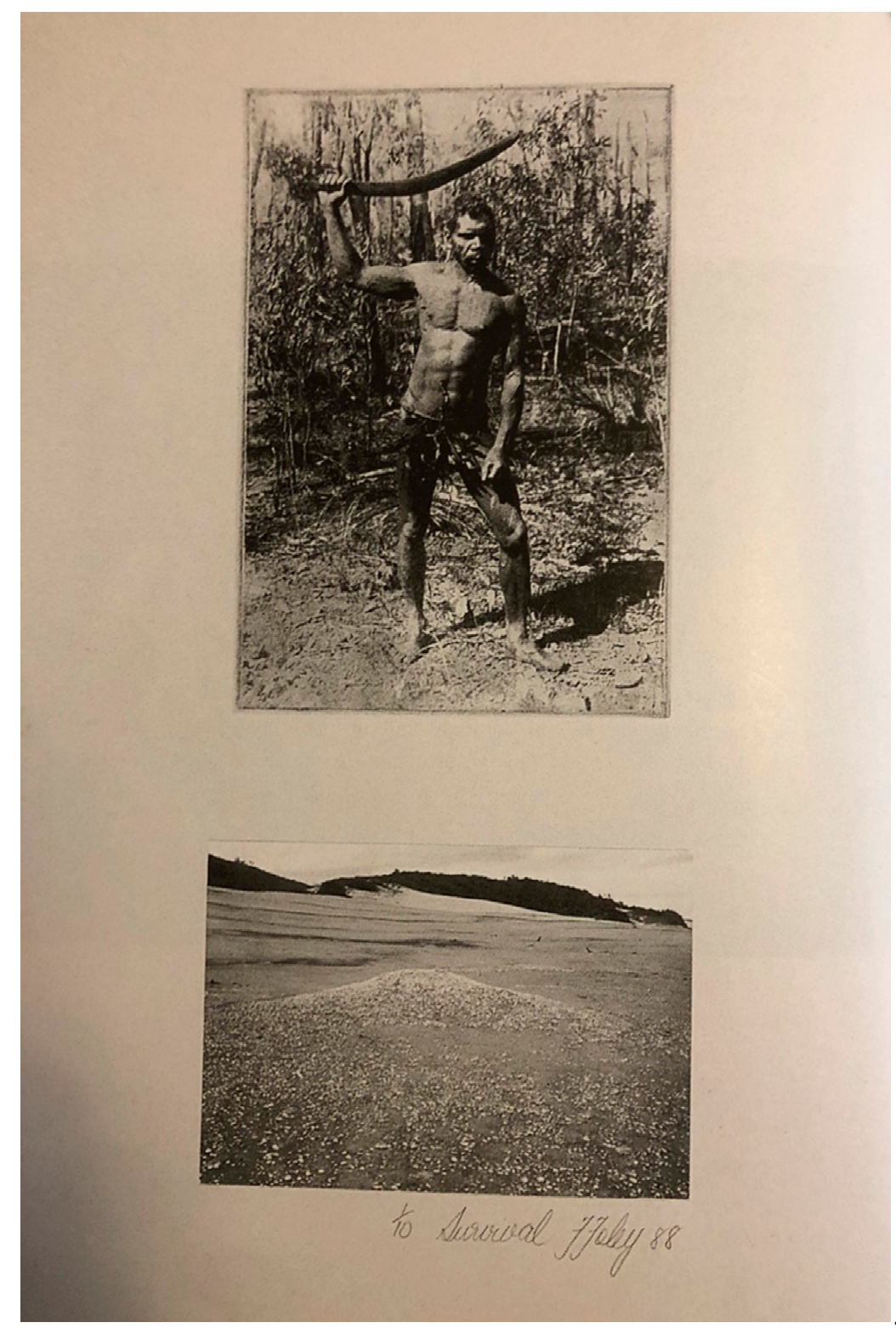

Figure 2. Fiona Foley's Survival III, IV (1988) Photo etching and collage on brown paper. Edition 2/10. Two of four sheets: $56.5 \times 38 \mathrm{~cm}$ (each). Courtesy of Queensland Art Gallery and Gallery of Modern Art, Brisbane, Australia. 
Funding: This research received no external funding.

Conflicts of Interest: The author declares no conflict of interest.

\section{References}

Allas, Tess. 2010. History is a Weapon: Fiona Foley History Teacher. Blak on Blak, Artlink 30: 56-61.

Buchanan, Kallee, Kay Ross, and Ford Elaine. 2014. Fraser Island: Native Title Rights GRAnted to Indigenous People by Federal Court. ABC News. November 6. Available online: https://www.abc.net.au/news/2014-1024/federal-court-rules-on-fraser-island-native-title/5839474 (accessed on 1 February 2020).

Courtney, Kris, and Ian J. McNiven. 1998. Clay Tobacco Pipes from Aboriginal Middens on Fraser Island, Queensland. Australian Archaeology 47: 44-53. [CrossRef]

Foley, Fiona. 1999. A blast from the past. In Constructions of Colonialism: Perspectives on Eliza Fraser's Shipwreck. Edited by Ian J. McNiven, Lynette Russell and Kay Schaffer. Sydney: Bloomsbury Publishing, pp. 163-73.

Foley, Shirley. 2018. Badtjala-English, English-Badtjala Word List: Badtjala Dictionary. Edited by Fiona Foley. Queensland: Wondunna Aboriginal Corporation.

Foster, Hal. 1996. The Artist as Ethnographer. In The Return of the Real. Cambridge: MIT Press, pp. 177-203.

Genocchio, Benjamin. 2001. Fiona Foley: Solitaire. Annandale: Piper Press.

Helmrich, Michelle, ed. 2009. Fiona Foley: Forbidden. Sydney: Museum of Contemporary Art and Brisbane, St Lucia: The University of Queensland Art Museum.

Lydon, Jane. 2014. Calling the Shots: Aboriginal Photographies. Canberra: Aboriginal Studies Press.

Martin-Chew, Louise. 2017. Fiona Foley Discusses Her New Series Horror Has a Face. Art Guide. December 6. Available online: https://artguide.com.au/fiona-foley-discusses-her-new-series-horror-has-a-face (accessed on 1 February 2020).

Martin, Lee-Ann, and Gerald McMaster, eds. 1992. Indigena: Contemporary Native Perspectives in Canadian Art. Vancouver: Douglas \& McIntyre.

Kembrey, Melanie. 2020. Artist Fiona Foley Explores How Opium Was Used to Control Aboriginal Labour. Sydney Morning Herald. January 3. Available online: https://www.smh.com.au/culture/art-and-design/artistfiona-foley-explores-how-opium-was-used-to-control-aboriginal-labour-20191230-p53niv.html (accessed on 7 April 2020).

McDonald, Helen. 2000. Erotic Ambiguities: The Female Nude in Art. New York: Routledge.

Pinney, Christopher. 2011. Photography and Anthropology. London: Reaktion Books.

Sinclair, John. 1990. Fraser Island and Cooloola. Sydney: Ure Smith Press.

Taylor, Andrew, Rachel Lane, Colin Friels, and The Australia Department of the Environment, Water, Heritage, and the Arts. 2009. Secret E Sacred: Badtjala. Rockdale: Squirrelgrip Films. DVD, 52m 30s.

Tyquiengco, Marina. 2016. Rewriting Ethnographic Photography: Reuse of Ethnographic Photography by Contemporary Indigenous Artists. Master's thesis, University of Pittsburgh, Pittsburgh, PA, USA. Available online: https://www.haa.pitt.edu/sites/default/files/Qualifying\%20Paper.\%20Marina\% 20Tyquiengco.\%20ETD.pdf (accessed on 4 July 2020).

Williams, Fred. 1982. Written in the Sand: A History of Fraser Island. Milton: The Jacaranda Press.

(C) 2020 by the author. Licensee MDPI, Basel, Switzerland. This article is an open access article distributed under the terms and conditions of the Creative Commons Attribution (CC BY) license (http://creativecommons.org/licenses/by/4.0/). 